\title{
Cytological and Autoradiographic Studies of the Effects of Vincaleukoblastine (VLB) on the Root Meristem Cells of Vicia faba
}

\author{
Sharda Srivastava, S. R. V. Rao, and V. C. Shah \\ Department of Zoology, University of Delhi, Delhi-7, India
}

Received March 4, 1971

The effects of Vincaleukoblastine (VLB) have been studied on the tissue culture cells, ascites tumor cells and normal bone marrow cells (Palmer et al. 1960, Cardinali et al. 1961, Cutts 1961). In these studies, it has been shown that VLB acts like colchicine as it produces mitotic arrest resulting in accumulation of metaphases. We have studied the effects of VLB on the lateral root meristem cells of Vicia faba and report the drug's effect on mitosis and macromolecular synthesis.

\section{Material and methods}

Growth conditions: Seeds of Vicia faba (A. L. Castle Inc.) were soaked and washed in running tap water for 24 hours. Seed coats were removed and primary roots were allowed to grow at $21^{\circ} \mathrm{C}$. Only the secondary roots measuring $2-3 \mathrm{~cm}$ were utilized. The following VLB concentrations $10 \mu \mathrm{gm}, 15 \mu \mathrm{gm}, 20 \mu \mathrm{gm}$ and $25 \mu \mathrm{gm} / \mathrm{ml}$ at $\mathrm{pH} 6.4$ were used. All experiments were carried out under controlled temperature of $21 \pm 2{ }^{\circ} \mathrm{C}$.

Continuous treatment: Four seedlings with a large number of roots were immersed in each concentration of drug and four seedlings each were maintained in distilled water as controls. At various intervals ranging from 6 to 24 hours, 4 root tips were excised from the above seedlings and fixed in acetic alcohol. In another experiment, the roots were continuously treated with $25 \mu \mathrm{gm} / \mathrm{ml} \mathrm{VLB}$ for 12 hours and fixed every hour. Roots were stained with Feulgen and permanent squash preparations were made.

Brief treatment and recovery: From the above studies, we found that $25 \mu \mathrm{gm} /$ $\mathrm{ml}$ dose was most effective and was used in all the subsequent experiments. Roots were exposed for 6 hours and transferred to distilled water after a thorough washing. The distilled water was changed once in 24 hours. At various intervals of $6,12,18,24$ and 48 hours, root tips were fixed in acetic alcohol.

$V L B$ in combination with aminoacids: Glutamic acid $\left(3.3 \times 10^{-3} \mathrm{M}\right)$ and cysteine solution $\left(10^{-3} \mathrm{M}\right)$ were used in combination with the drug. Adequate number of roots were fixed at 6,12 and 24 hours after each treatment. Both the treated and their respective control roots were fixed in acetic alcohol and stained with Feulgen and permanent squash preparations were made.

Autoradiography: The effects of VLB on the synthesis of DNA, RNA and protein were studied by exposing roots to $\mathrm{H}^{3}$-thymidine $3 \mu \mathrm{c} / \mathrm{ml}$ (Sp. Act. $6.0 \mathrm{C} / \mathrm{mM}$ ), 
$\mathrm{H}^{3}$-uridine $5 \mu \mathrm{c} / \mathrm{ml}$ (Sp. Act. $1.1 \mathrm{C} / \mathrm{mM}$ ), $\mathrm{H}^{3}$-lysine $3 \mu \mathrm{c} / \mathrm{ml}$ (Sp. Act. $20.5 \mathrm{mC} / \mathrm{mM}$ ) and $\mathrm{H}^{3}$-arginine $3 \mu \mathrm{c} / \mathrm{ml}$ (Sp. Act. $247 \mathrm{mC} / \mathrm{mM}$ ) as suitable precursors for $30 \mathrm{mi}$ nutes. The radioactive precursors were obtained from Bhabha Atomic Research Centre, Trombay, Bombay. Samples were fixed immediately after treatment and were processed for autoradiography. Squash preparations were dipped in Kodak NTB-3 emulsion. $\mathrm{H}^{3}$-thymidine and $\mathrm{H}^{3}$-uridine slides were exposed for 4 weeks, $\mathrm{H}^{3}$-arginine for 10 days and $\mathrm{H}^{3}$-lysine for 5 days. All slides were developed for 3 minutes in Kodak 19B developer and fixed in acid fixer. The percentage of labelled interphase cells was determined from a total of 3,000 cells. Grain counts from $\mathrm{H}^{3}$-thymidine slides were made from 100 whole nuclei, both from control and treated roots. Grain counts from $\mathrm{H}^{3}$-uridine, $\mathrm{H}^{3}$-lysine and $\mathrm{H}^{3}$-arginine slides were made through a reticule encircling a constant area of $7.85 \mu^{2}$ from nucleus and/or cytoplasm. Quantitative estimation of DNA per nucleus was made by a cytophotometer as described by Swift and Rasch (1956) using wavelength $570 \mathrm{~m} \mu$.

\section{Observations}

Continuous treatment: The effects of various concentrations of VLB on the mitotic index is shown in figure 1. The continuous treatment of VLB for 6 hours had little or no effect on mitotic index at $10 \mu \mathrm{gm} / \mathrm{ml}$ concentration while at $15 \mu \mathrm{gm} /$ $\mathrm{ml}$ and $20 \mu \mathrm{gm} / \mathrm{ml}$ showed slight effect. However, $25 \mu \mathrm{gm} / \mathrm{ml}$ for similar hours reduced the mitotic index by nearly 50 per cent. A 12 hour treatment resulted in a further decrease in the mitotic index. At $15 \mu \mathrm{gm} / \mathrm{ml}$ and $20 \mu \mathrm{gm} / \mathrm{ml}$ the mitotic index was reduced by 31.08 and 45.58 per cent, respectively and at $25 \mu \mathrm{gm} / \mathrm{ml}$ it was reduced by 88.72 per cent. On prolonging the treatment to 24 hours, $15 \mu \mathrm{gm} /$ $\mathrm{ml}$ and $20 \mu \mathrm{gm} / \mathrm{ml}$ dosage decreased the mitotic index by 38.95 and 65.12 per cent respectively. The treatment with $25 \mu \mathrm{gm} / \mathrm{ml}$ showed more or less complete inhibition ( 98.45 per cent).

The frequencies of prophases were also affected. The effect was both dose and duration dependent (Fig. 2a). However, $25 \mu \mathrm{gm} / \mathrm{ml}$ was found to be most effective as it virtually inhibited almost all prophases by 12 hours ( 99 per cent).

The percentage of metaphases was observed to increase at 6 hours with all the concentrations and especially, $25 \mu \mathrm{gm} / \mathrm{ml}$ dosage. However, at 12 hours a gradural decline was seen (Fig. 2b)

During the continuous treatment with $25 \mu \mathrm{gm} / \mathrm{ml}$ VLB the effect was seen as early as 2 hours after treatment. The percentage of prophases showed a sharp decline and at 10 hours no prophases could be observed. There was an increase in the percentage of metaphases. The latter started declining after 8 hours of treatment and was below control levels at 12 hours (Fig. 3).

The post metaphasic stages showed reduction at all concentrations. The reduction in the number of anaphases indicated an inhibition of spindle mechanism.

Recovery: When the treated roots were recovered in distilled water the mitotic index initially decreased and reached to 1.5 per cent during the first 6 hours of recovery i.e. at 12 hours (Fig. 4). But at 12 hours there was a sudden burst of mitosis resulting in a rapid rise of mitotic index to 10 per cent. In general, all 
the mitotic stages showed recovery (Fig. 4). The recovery of prophases was not complete since the percentage of prophase was always below control level.

Glutamic acid $\left(3.39 \times 10^{-3} \mathrm{M}\right)$ and cystein $\left(10^{-3} \mathrm{M}\right)$ prevented mitotic arrest and prophase inhibition to varying degrees. Glutamic acid reversed the action of

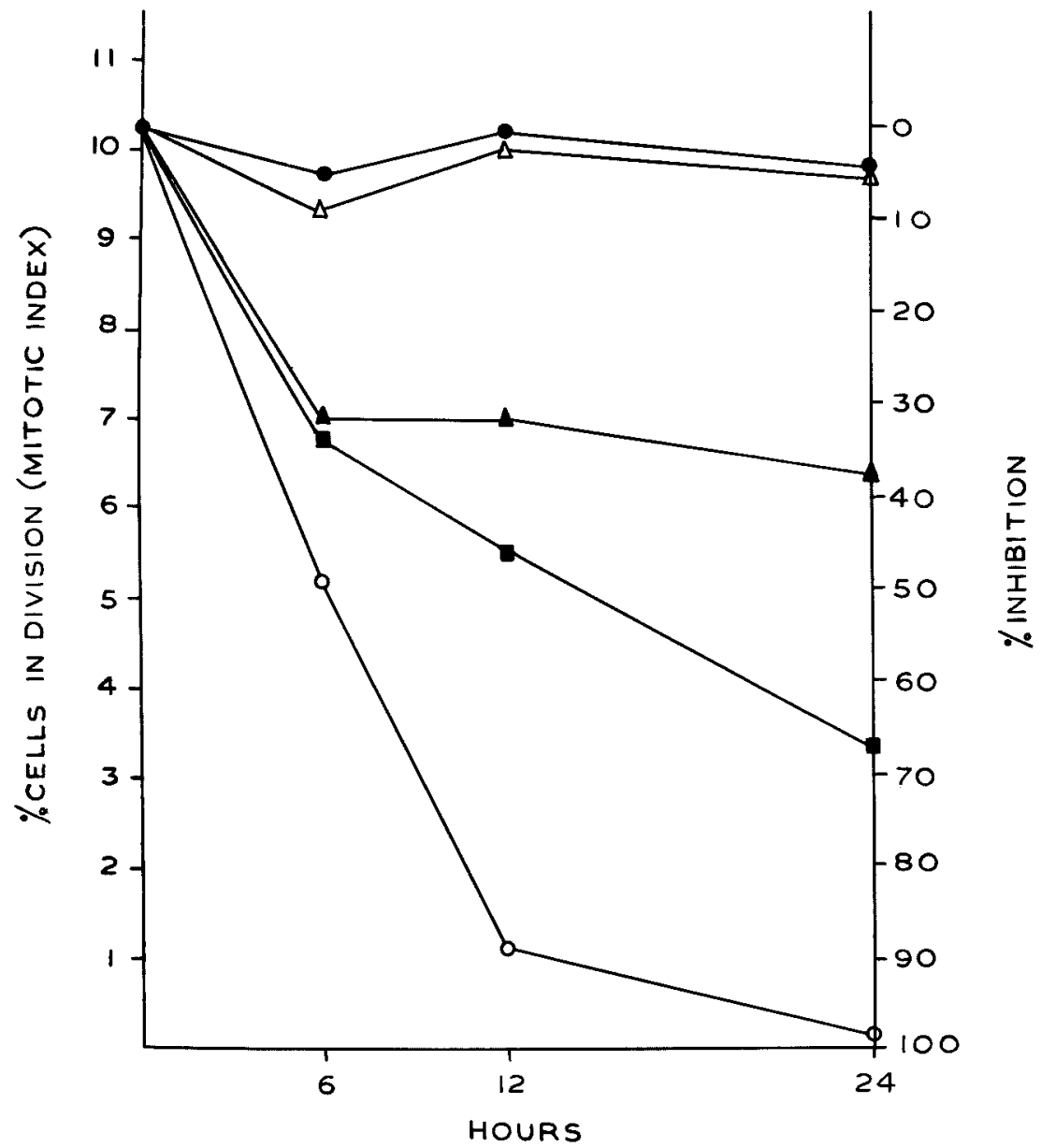

Fig. 1. Effects of various concentrations of VLB on mitosis in lateral roots of Vicia faba. Solid circle-untreated control; hollow triangle-VLB treatment $10 \mu \mathrm{gm} / \mathrm{ml}$; solid triangle-VLB treatment $15 \mu \mathrm{gm} / \mathrm{ml}$; solid square-VLB treatment $20 \mu \mathrm{gm} / \mathrm{ml}$; open circule-VLB treatment $25 \mu \mathrm{gm} / \mathrm{ml}$.

VLB on mitotic index (Fig. 5). It prevented prophase inhibition at 6 hours as the percentage of prophase was $6.39 \%$ as in controls $(5.51 \%)$. Glutamic acid also reversed the metaphase arrest. Cystein was more effective in preventing the metaphase arrest but did not prevent prophase inhibition.

Morphological effects: With $25 \mu \mathrm{gm} / \mathrm{ml}$ concentration for 12 hours, most of the chromosomes were highly condensed and sticky. Spindle disruption was ap- 

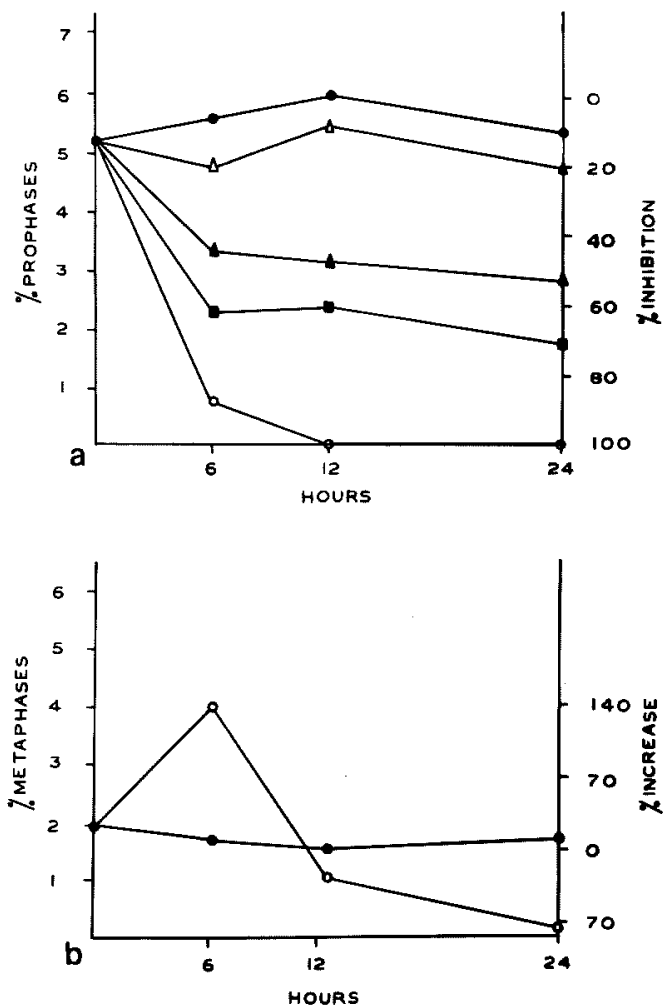

Fig. 2. Effects of various concentrations of VLB on different stages of mitosis. 2a-prophase; $2 b-$ metaphase. Legend same as in Fig. 1.

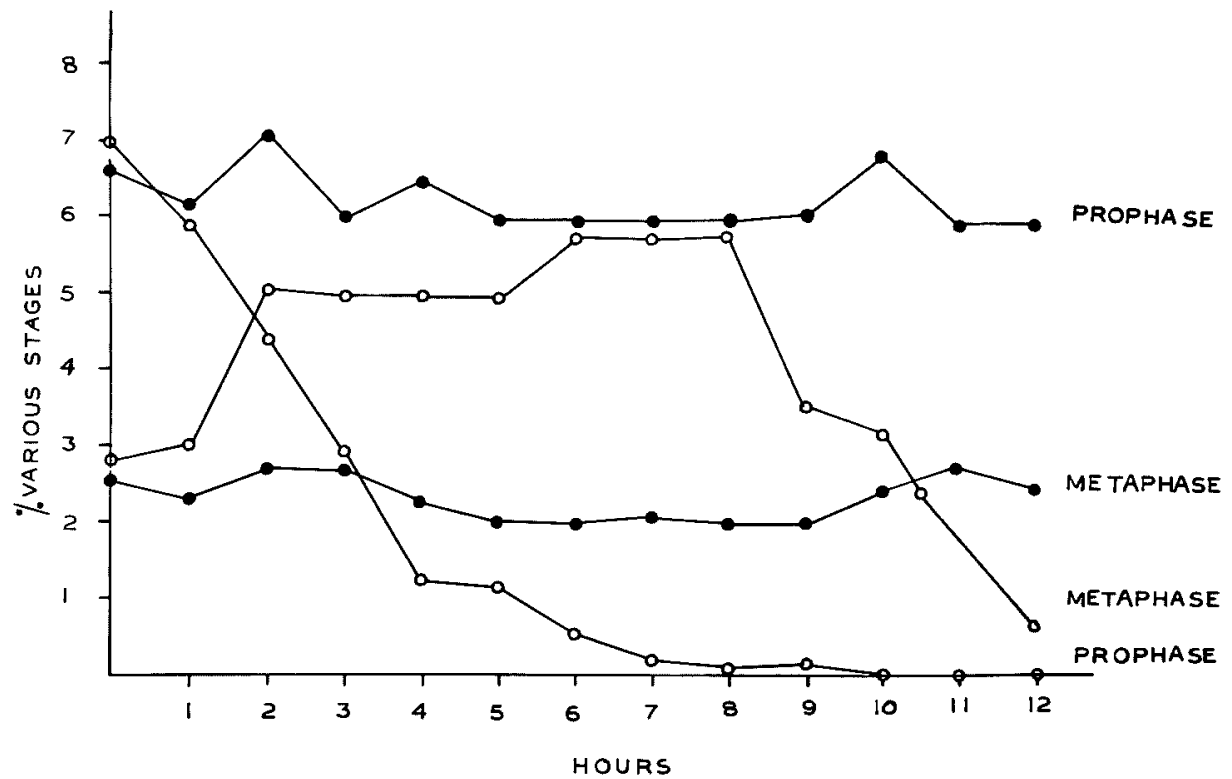

Fig. 3. Effects of $25 \mu \mathrm{gm} / \mathrm{ml}$ VLB on prophases and metaphases. 1) Solid circle-untreated control; 2) hollow circle-VLB treated $(25 \mu \mathrm{gm} / \mathrm{ml})$. 


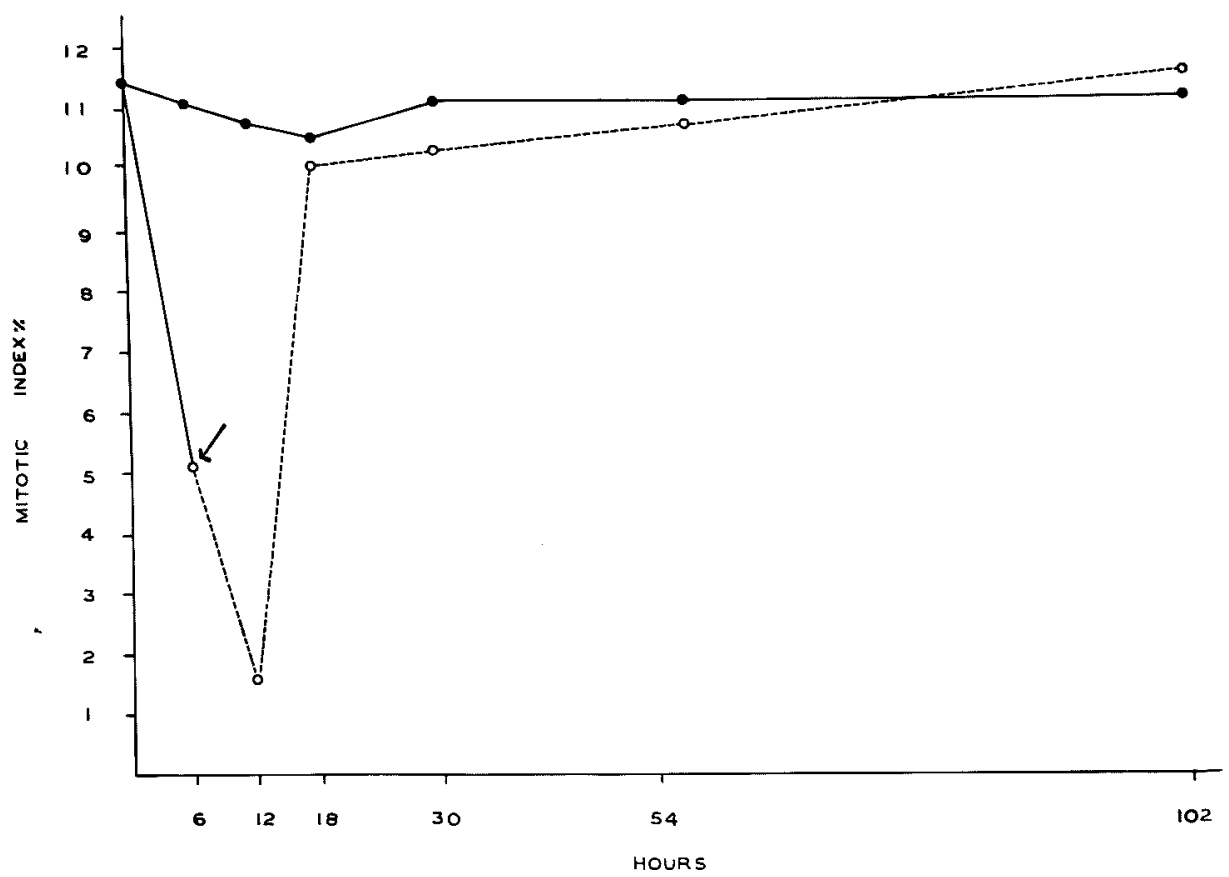

Fig. 4. Mitotic recovery of Vicia faba cells in distilled water (open circle with dotted lines). Arrow indicates transfer of roots after 6 hours treatment to recovery medium.

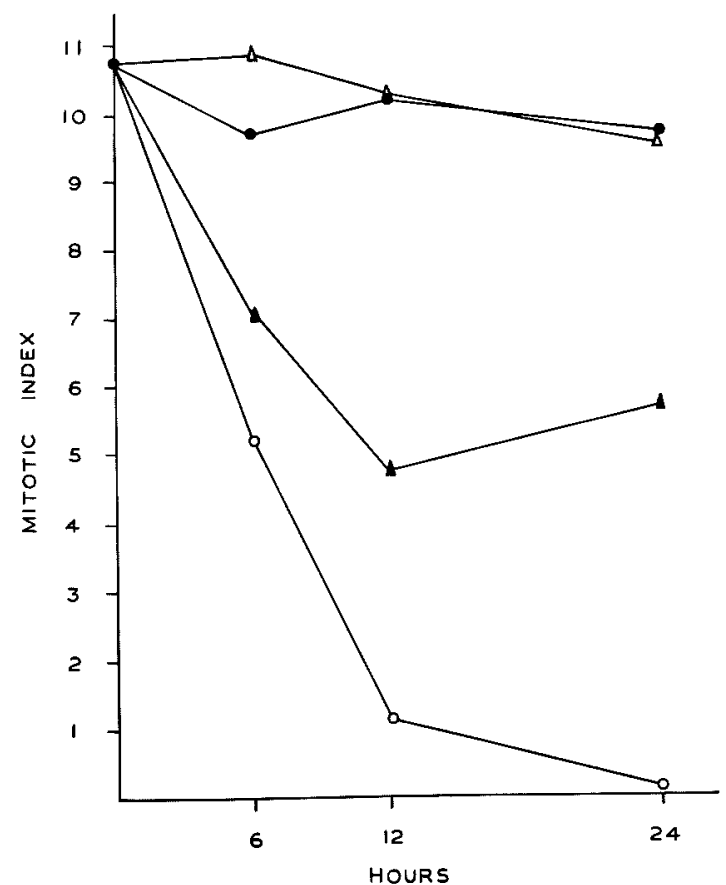

Fig. 5. Effect of VLB $(25 \mu \mathrm{gm} / \mathrm{ml})$ in combination with glutamic acid on mitosis. Solid circledistilled water control; hollow triangle-VLB plus glutamic acid; solid triangle-glutamic acid control; open circle-VLB in distilled water. 
parent as no post metaphasic stages were observed and large number of micronuclei were seen.

Effect of VLB on macromolecular synthesis: Feulgen cytophotometric measurements indicated a reduction in DNA content in the VLB treated nuclei. The mean DNA content was 789.14 in arbitrary units in treated nuclei as compared to 1058.31 in controls. Autoradiography data (Table 1) also suggested DNA inhibition (Fig. 6a, b) as the incorporation of label in individual nuclei showed a mean grain count of $116.20 \pm 2.62$ in controls as compared to $75.91 \pm 2.77$ in the treated nuclei. However, the percentage of labelled cells was about the same in treated (56.94) as well as in controls (59.79).

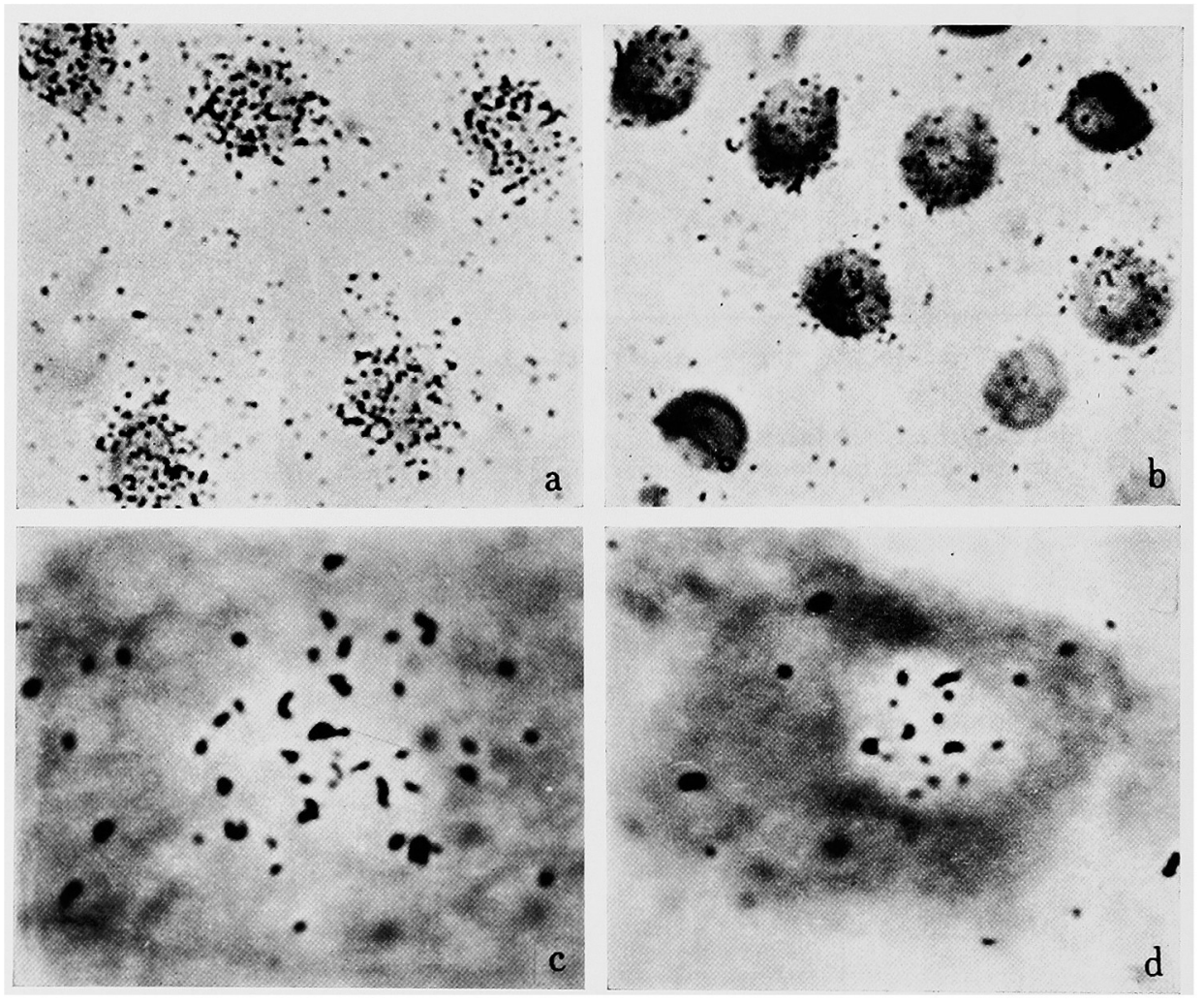

Fig. 6. Autoradiographs showing the effects of VLB on the incorporation of labelled precursor into DNA (a, b) and RNA (c, d). a) $\mathrm{H}^{3}$-thymidine incorporation in control cells. $\times 800$; b) $\mathrm{H}^{3}$-thymidine incorporation in treated cells. $\times 800$; c) $\mathrm{H}^{3}$-uridine incorporation in control cells. $\times 2,000 ;$ d) $\mathrm{H}^{3}$-uridine incorporation in treated cells. $\times 2,000$.

The mean grain count in $\mathrm{H}^{3}$-uridine slides over an unit area of nucleus was $25.00 \pm 0.76$ in controls as against $10.00 \pm 0.43$ in treated roots (Table 1) suggesting a significant inhibition of RNA synthesis (Fig. 6c, d).

Using $\mathrm{H}^{3}$-lysine and $\mathrm{H}^{3}$-arginine the incorporation of these into protein was studied. VLB treatment had an inhibitory effect on protein synthesis (Figs. 7ab, cd). $\mathrm{H}^{3}$-lysine incorporation was inhibited considerably at 6 hours. The mean 
Table 1. Effect of VLB $(25 \mu \mathrm{gm} / \mathrm{ml}, 6 \mathrm{hrs}$. $)$ on the incorporation of $\mathrm{H}^{3}$-thymidine, $\mathrm{H}^{3}$ uridine, $\mathrm{H}^{3}$-arginine and $\mathrm{H}^{3}$-lysine in the lateral root meristem cells of $V$. $f a b a$

\begin{tabular}{l|l|c|c|c}
\hline \multicolumn{1}{c|}{$\begin{array}{c}\text { Labelled } \\
\text { Compound }\end{array}$} & & Control & Treated & $\begin{array}{c}\% \\
\text { Inhibition }\end{array}$ \\
\hline H $^{3}$-thymidine & Nucleus & $116.20 \pm 2.62$ & $75.91 \pm 2.77$ & 34.69 \\
H $^{3}$-uridine & Nucleus & $25.00 \pm 0.76$ & $10.00 \pm 0.43$ & 60.00 \\
H $^{3}$-arginine & Nucleus & $36.10 \pm 1.25$ & $13.09 \pm 0.44$ & 63.88 \\
& Cytoplasm & $24.0 \pm 0.88$ & $19.0 \pm 0.70$ & 20.83 \\
H $^{3}$-lysine & Nucleus & $42.0 \pm 1.1$ & $19.0 \pm 0.55$ & 54.76 \\
& Cytoplasm & $61.0 \pm 1.5$ & $31.0 \pm 0.88$ & 49.18 \\
\hline
\end{tabular}

* 30 minutes label.

Note: Grain count determinations were made on 100 interphase nuclei over an unit area of cytoplasm and nucleus. In case of $\mathrm{H}^{3}$-thymidine the grain count was made on 100 interphase nuclei only.

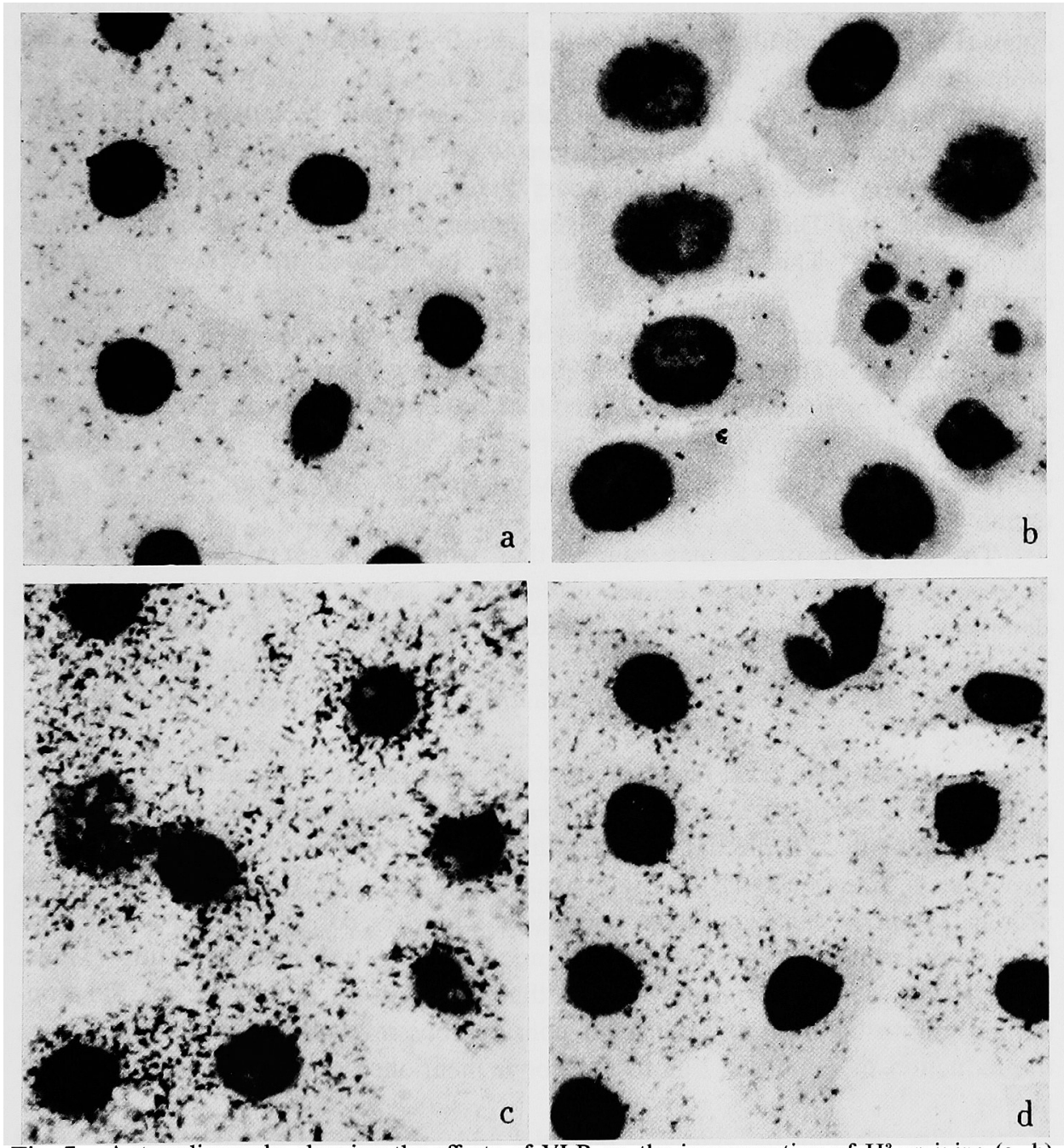

Fig. 7. Autoradiographs showing the effects of VLB on the incorporation of $\mathrm{H}^{3}$-arginine $(\mathrm{a}, \mathrm{b})$ and $\mathrm{H}^{3}$-lysine $(\mathrm{c}, \mathrm{d})$ into protein. a, c controls $\times 800$. b, $\mathrm{d}$ treated $\times 800$. 
grain count in treated cells was $31 \pm 0.88$ in cytoplasm and $19.0 \pm 0.55$ in nucleus as compared to $61 \pm 1.5$ and $42 \pm 1.1$ of controls. In case of $\mathbf{H}^{3}$-arginine the mean grain count per unit area over cytoplasm was $19.0 \pm 0.70$ and in nucleus it was $13.09 \pm 0.44$ in treated cells, whereas it was $24 \pm 0.88$ and $36.10 \pm 1.25$ grains, respectively, in controls (Table I).

\section{Discussion}

Earlier studies (Palmer et al. 1960, Cardinali et al. 1961, Cutts 1961) indicated that VLB interfered with cell division in animal tissues resulting in an increase in the mitotic index due to accumulation of metaphases. The present study has shown that in addition to its effect on metaphases, VLB has some effect on prophases as well as post-metaphasic stages. This results in the reduction in mitotic index (Fig. 1). A similar effect was also seen by Deysson et al. (1963) in onion roots treated by VLB.

Our experiments of continuous treatment show that metaphase block begins at 2 hours after treatment and continues up to 8 hours resulting in the accumulation of metaphases. However, after 2 hours the frequency of prophases is seen to reduce (Fig. 3). This fall in prophases appears to be due to the inhibition at interphase $\left(\mathrm{G}_{2}\right)$. This interphase block was investigated in detail in recovery experiments.

It was seen that most of the treated roots recover in distilled water after a brief treatment. The frequencies of prophases, post metaphasic stages and the mitotic index, in general, reestablished more nearly as in controls $(10.6 \%)$. Since the treated cells recovered within 6 hours it seemed that recovery may be due to the release of the block in $G_{2}$ which is approximately 4 to 6 hours (Sharda et al., unpublished).

The inhibition of $\mathrm{G}_{2}$ may suggest that synthesis of some proteins or RNA necessary for mitosis was blocked. Analysis of autoradiograms clearly indicate significant inhibition of both RNA and protein synthesis. It is interesting to note that Richards et al. (1966) and Creasy et al. (1965) also found inhibition of RNA in thymus cell suspensions and Ehrlich ascites cells, respectively, after VLB treatment.

Treated cells can however, overcome the effects of VLB when they are exposed to glutamic acid and cystein prior to treatment or simultaneously along with the drug. Although the mechanism of glutamic acid in reversal remains obscure, nevertheless Creasy (1965) envisages that glutamic acid in someway regulates protein synthesis through RNA synthesis. There is considerable evidence that $\mathrm{SH}$ groups containing proteins play an important role in spindle formation (Mazia et al. 1958). Our experiments showed that the addition of cystein, an SH containing amino acid, along with VLB considerably reverses the inhibition. Thus the reduction of inhibition due to the above mentioned amino acid is understandable.

Besides affecting the synthesis of RNA and proteins, VLB was found to affect DNA synthesis as seen from cytophotometry and autoradiography data. But 
the interference concerns only with the rate of DNA synthesis rather than the inhibition of DNA per se. The percentage of labelled interphase cells remains more or less the same in both the treated (56.94) and control (59.79) although the photometric and grain count data (Table 1) indicates slight reduction in the amount of DNA. However, Richards et al. (1966) seem to have observed a significant inhibition of DNA in VLB treated thymus cells.

The morphological effects like chromosome condensation and $\mathrm{C}$-mitosis are most likely due to the secondary effects of prolonged metaphases rather than the direct action of VLB on chromosomes.

\section{Acknowledgement}

Our thanks are due to Professor B. R. Seshachar, Chairman, Department of Zoology, University of Delhi, Delhi-7, for his sustained interest. This work was supported in part by the grants from the University Grants Commission to the Centre of Advanced Study in Cell Biology and Endocrinology, Department of Zoology, and the Atomic Energy Commission, India. We thank Mr. E. A. Daniels for photography. The generous gift of Vinblastine by Dr. J. M. McGuire, The Lilly Research Laboratories, Indianapolis, U.S.A. is gratefully acknowledged.

\section{Literature cited}

Cardinali, G., Cardinali, G. and Blair, J. 1961. The stathmokinetic effect of vincaleukoblastine on normal bone marrow and leukemic cells. Cancer Res. 21: 1542-1544.

Creasy, W. A. and Markiw, M.E. 1965. Biochemical effects of the vinca alkaloids III. The synthesis of ribonucleic acid and the incorporation of aminoacids in Ehrlich ascites cells in vitro. Biochim. Biophys. Acta 103: 635-645.

Cutts, J. H. 1961. The effects of vincaleukoblastine on dividing cells in vivo. Cancer Res. 21: $168-172$.

Deysson, G. et Thruhaut, Rene. 1963. Etude, sur le test Allium de l'activite antimitotique de la vincaleukoblastine. Competes Rendus 256: 3512-3515.

Mazia, D. and Zimmerman, A. M. 1958. SH compounds in mitosis III. The effects of mercaptoethanol on the structure of mitotic apparatus in sea urchin eggs. Exp. Cell Res. 15: 138152.

Palmer, C. G., Livengood, D., Warren, A. K., Simpson, P. J. and Johnson, I. S. 1960 . The action of vincaleukoblastine on mitosis in vitro. Exp. Cell Res. 20: 198-201.

Richards, J. F., Jones, R. G. W. and Beer, C. T. 1966. Biochemical studies with the vinca alkaloids I. Effects on nucleic acid formation by isolated cell suspension. Cancer Res. 26: 876-881.

Swift, H. and Rasch, E. 1956. In "Physical Techniques in Biological Research" (G. Oster and A. W. Pollister, eds), Vol. III, p. 354, Academic Press, New York. 